\title{
Makers and Markers of Distinction: Technology and Amish Differentiation in the 1935-1936 Study of Consumer Expenditures
}

\author{
Steven D. Reschly ${ }^{1}$ \\ Professor, History Department \\ Truman State University \\ Kirksville, Missouri
}

\begin{abstract}
Plain groups differentiate themselves from the world, and from one another, by technology. It is worth recalling, however, that before the late nineteenth and early twentieth centuries, Amish farmers and artisans used the same technologies as their neighbors, and were often more advanced than those around them in agricultural techniques and tools. This article examines the early development of technological differences as markers of subcultural boundaries based the massive Study of Consumer Purchases (S.C.P.) conducted by the Bureau of Labor Statistics in the U.S. Department of Labor, and the Bureau of Home Economics in the U.S. Department of Agriculture in 1935 and 1936.
\end{abstract}

\section{Keywords}

Amish; technology; Study of Consumer Purchases; group differentiation; church discipline; 1930s; Lancaster County, PA

\section{Acknowledgements}

The author would like to thank Katherine Jellison and an anonymous reader at Mennonite Quarterly Review for helpful comments on earlier drafts.

Reschly, Steven D. 2014. "Makers and Markers of Distinction: Technology and Amish Differentiation in the 1935-1936 Study of Consumer Expenditures." Journal of Amish and Plain Anabaptist Studies. 2(1):125-146. 


\section{Introduction}

Plain groups differentiate themselves from the world, and from one another, by technology. Machinery, equipment, and other apparatuses that are forbidden, restricted, or allowed mark degrees of distinction. Clothing, language, buggy style, congregating in homes and barns for worship rather than meetinghouses, and historic beliefs regarding adult baptism, military service, and separation from the outside world also interact in Amish discourses of distinction. During the twentieth century, Amish constructions of their relationship with the world within Amish communities focused increasingly on technology. Groups retaining an Amish identity consistently and firmly rejected those technologies and social changes that most drastically shifted the scale of rural life: automobiles, telephones, grid electricity, tractors, school consolidation, mass communication devices like radios and consumer magazines, and state-level compulsory education laws.

Technology was not then the central issue of Amish life and faith that it seems to be, or is assumed to be, in the early twenty-first century. It is worth recalling, however, that before the late nineteenth and early twentieth centuries, Amish farmers and artisans used the same technologies as their neighbors, and were often more advanced than those around them in agricultural techniques and tools. (Reschly 2000; Konersmann 2008; Konersmann 2012; Konersmann and Lorenzen-Schmidt 2011)

\section{Technology and Religious Subcultures}

Technological issues are glaringly absent, for example, from the mid-nineteenth-century Diener Versammlungen minutes. These records of gatherings of Amish leaders between 1862 and 1878 showed more concern with matters of church discipline, participation in politics and nonchurch organizations, the nature of salvation, methods of baptism, fashionable clothing, bureaucracy, revivalism, and military service. Internal conflicts and schisms resulted over these issues, none of which had to do with technology or what might generously be termed “modernity” (Yoder and Estes 1999; Yoder 1991). Their relationship with technology evolved from a virtual non-factor to an apparent central marker in Amish life and in studies of the Amish (Kraybill, Johnson-Weiner, and Nolt 2013; Beachy 2011; Nolt 2003; Johnson-Weiner 2014; Petrovich 2014).

Historians of rural and agricultural societies in many parts of the world have researched the shifts in the economics and social structures of rural life wrought by the telephone, the automobile, consolidated education systems, the tractor, market and consumer capitalism, and the power grid (Loewen 2006; Anderson 2009; Barron 1997; Danbom 2006). Many religious and ethnic communities in North America resisted these changes, sensing their destructive force, though few were successful in retaining a small-scale way of life or even slowing down the influence of these transformative technologies and political economies. The Amish stood out with increasing visibility during the twentieth century because they successfully eschewed or 
limited these modifiers of rural life. The buggy, as the ultimate emblem of Amishness, could not and did not occupy that privileged position in the nineteenth century or the early twentieth century.

The shifts in scholarly and public awareness of Amish distinctiveness, and the shifts in Amish self-understanding, are increasingly well understood in terms of tourism and public policy accommodations to their religious beliefs, such as alternative military service and parochial schools (Trollinger 2012; Weaver-Zercher 2001; Kraybill 2003). The economic and technological processes by which the Amish became visibly and markedly different from mainstream American and Canadian societies and political economies are less researched and understood. In brief, new technologies triggered many internal debates in Amish communities in the late nineteenth and early twentieth centuries, while their rejection or limited use of some technologies became the best known and publicized characteristic of Amish society in mainstream culture after World War II. The 1930s was a crucial decade in this process of social and cultural differentiation (Zimmerman-Umble 1996; Gingerich 1939; Kraybill and Olshan 1994).

Amish religious values shaped these historic transitions, filtering rural transformative technologies on Amish farms and in Amish communities. These principles had developed as a result of Anabaptist and Amish historical experience in Central Europe and North America, and were buttressed by Anabaptist Biblical interpretations, such as separation from the world, nonconformity to the world, non-bureaucratic and decentralized congregational polity, egalitarian communal decision-making and leadership, and avoidance of violence (Reschly 2000, chapter one). The labor of Amish women and children facilitated the rejection or partial adaptation of the machines and devices that altered the society and economy around them, allowing these small-scale rural ideals to survive. Household production of food, clothing, and furnishings made possible some degree of independence from the urbanizing fossil fuel economy of North America (Reschly and Jellison 1993; Jellison 2014).

\section{The Study of Consumer Purchases}

These assertions about intertwined gender and technology are supported by evidence from the massive Study of Consumer Purchases (S.C.P.) conducted by the United States Government in 1935 and 1936. ${ }^{2}$ The study was conducted by the Bureau of Labor Statistics in the Department of Labor for large and small cities, and the Bureau of Home Economics in the Department of Agriculture for small towns and farms. The statistical reports and manuscript schedules offer uniquely detailed information about the everyday life of urban and rural households in diverse regions of the United States. The data were collected from 51 cities, 140 villages, and 66 farm counties, selected to represent the demographic, regional, and economic characteristics of the United States (Figure 1). From these areas a randomly selected group of approximately 700,000 families was screened as a first sample. From this first group, approximately 300,000 families were selected to supply basic income and housing information 
on a two-page form. Some 61,000 families were selected from this second group to furnish more comprehensive expenditure information by filling out a six-page form with over 800 variables. Rural counties represented 15 types of agriculture. Lancaster County, Pennsylvania, was selected to represent "general farming," a choice that reflected the distinctive interest of some officials in the U.S. Department of Agriculture in plain communities as models of social stability and economic survival ${ }^{3}$ (Jellison 2001; Jellison 2002).

\section{Figure 1: Consumer Expenditures Survey, 1935 to 1936: 51 Cities, 140 Villages, and 66 Farm Counties}

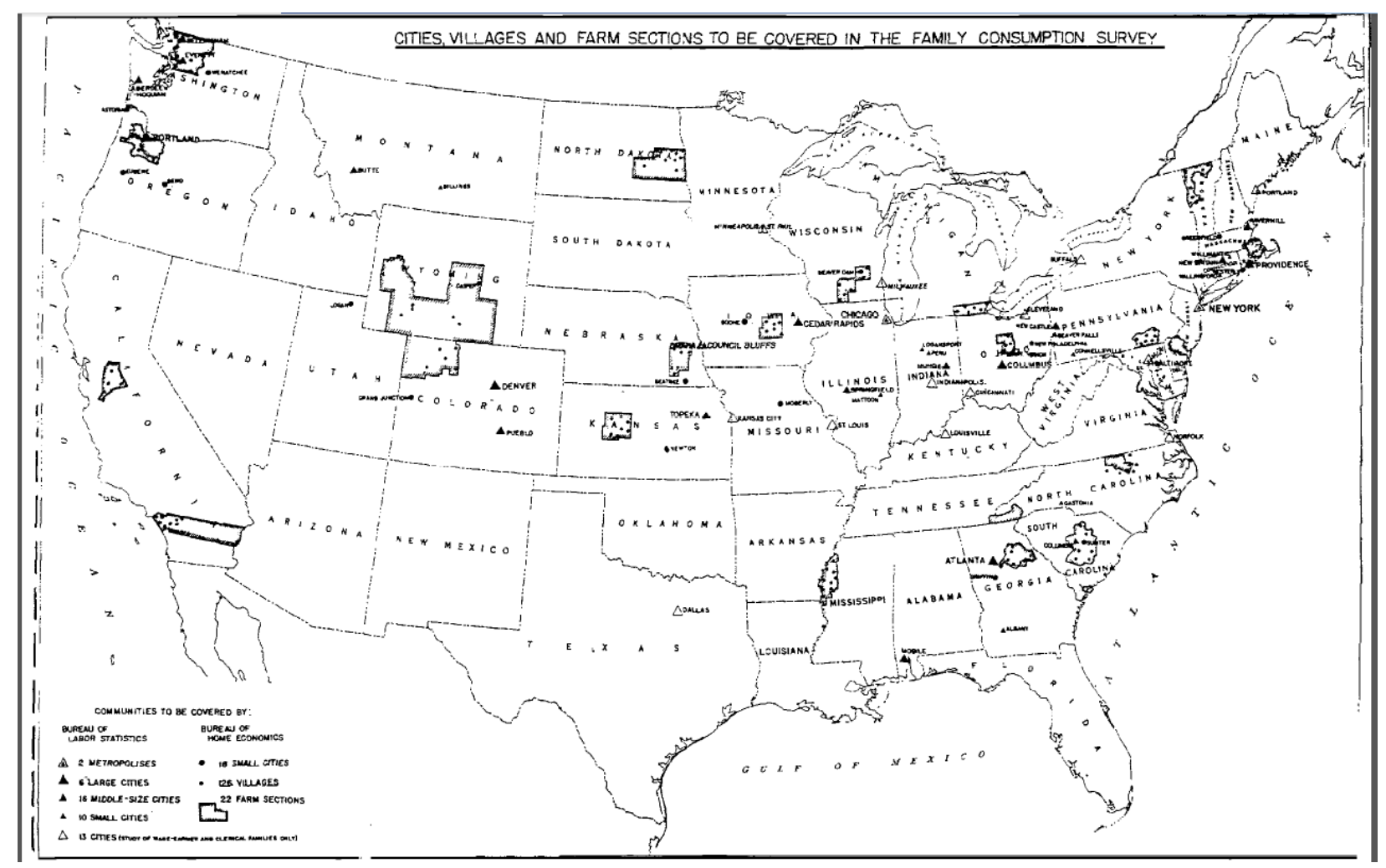

Families completed questionnaires that reported in detail all household income sources and expenditures during the previous year. Respondents were asked to record all income received by the family from each person employed as well as from other sources such as gifts, interest and dividends, and pensions. Families provided complete information on their composition, housing, fuel and other utility expenses, medical care, recreational activities, tobacco use, purchase of reading materials, educational expenses, miscellaneous occupational expenses, taxes paid, automobile expenses, personal care costs, and a detailed appraisal of all changes in family assets and liabilities. Families also reported the quantity of food items consumed, purchase price, and 
total expense of all food items consumed by the family in the seven days prior to the interview. In addition, families provided information about furnishings and equipment purchased for the home as well as about all items of clothing purchased for each family member in the previous year. Demographic characteristics recorded for all household members included their relationship to the household head, age, sex, occupation, weeks spent at home or away from home, wage rate, length of time employed during the year, and total earnings.

The Inter-University Consortium for Political and Social Research (I.C.P.S.R.) at the Institute for Social Research (I.S.R.) at the University of Michigan constructed a random sample dataset consisting of 5,000 records from the 300,000 families, and 6,000 records from the 61,000 families who completed at least the first and second schedules. The second dataset is a large sampling and thus can be analyzed with a high degree of confidence, although it must be remembered that these are, to some extent, self-selected families who were willing to provide all this information. I.C.P.S.R. organized the sample into four datasets: (1) urban income, (2) village and farm income, (3) urban expenditure schedule, and (4) village and farm expenditure schedule. With 6,000 of the 61,000 schedules included in the sample, statistical analysis can be performed with a $1.6 \%$ margin of error at a $99 \%$ confidence level. By way of contrast, a typical Gallup poll surveys about 1,000 adults of the 313 million people in the United States, producing a margin of error of about $\pm 4 \%$ at a $95 \%$ confidence level.

These data files are massive. The small town/farm dataset has 2,869 variables and 3,034 cases, producing 8,704,546 individual cells. The farm and small town codebook from I.C.P.S.R. is 6,849 pages in length. ${ }^{4}$ Survey agents hired by the Bureau of Home Economics collected 1,266 farm schedules in Lancaster County. Some 108 were selected for the I.C.P.S.R. random sample, or $8.5 \%$, by random chance slightly lower than the overall $10 \%$ sample. The forms have no questions for name, religious affiliation, or ethnicity-except for African American hous eholds in the South-but they do specify township. Of these 1,266 farm schedules in Lancaster County, I selected 394 schedules for intensive research: all those with any "plain” designation (including “Amish," "Mennonite," or simply "plain”), all those with food record schedules, and 31 of the 108 selected for the I.C.P.S.R. sample. The I.C.P.S.R. random sample is a useful statistical control for my selection of these records that focuses on plain groups.

Handwritten marginal notations on many schedules from Lancaster County identify the family as Amish or Mennonite, most often to explain the presence or absence of various expenditures. It seems the survey takers found it necessary to include written notes on the schedules rather than have the schedules returned by their supervisors with instructions to go back to the farms in order to fill in the blank spaces. ${ }^{5}$ In the 394 schedules from Lancaster County farm households under study, there are 86 with no notations, 97 with "Amish" written somewhere on one or more of the schedules, 105 with "Mennonite” noted, and 106 with "plain" in various forms, including two with "Church of the Brethren" and "Brethren People," and one with “Old Time Methodists” (Table 1). These notations, especially, offer a detailed glimpse into the farm households among a range of ethno-religious groups in Lancaster County. 


\section{Table 1: Written Notations on Expenditure Survey Schedules}

\begin{tabular}{llc}
\hline Religious Group & Description & Count \\
\hline None & No religious group specified, no note at all & 86 \\
Old Order Amish & “Amish” on survey & 74 \\
Team Mennonite & “Mennonite” on survey, no auto & 14 \\
Horse and Buggy Plain & Old Order Mennonite or Amish, unspecified & 42 \\
Beachy/Car Amish & “Amish” on survey, automobile or other technology & 23 \\
Plain with automobile & Unspecified & 64 \\
Mennonite & “Mennonite” on survey probably Lancaster Conference & 91 \\
\hline Total & & 394 \\
\hline
\end{tabular}

Some of the families labeled "Amish" owned automobiles, used power grid electricity, owned a telephone, farmed with a tractor, or otherwise proved not to be Old Order Amish. Therefore, the 97 records with “Amish” notations are categorized as 74 "Old Order Amish” and 23 "Beachy (or Car) Amish” households for study and statistical purposes. Conversely, 31 of those families labeled "Plain" have identical characteristics and were located in the same townships as those labeled “Amish” and, further, were consistent with the Old Order Amish Ordnung (consensual lifestyle regulations) in the 1930s. The uniformity of these additional 31 forms is remarkable: there are no automobile costs, no recreation expenditures, no haircut costs, no phone, no grid electricity, quite a bit of tobacco raising and use, occasional ice refrigerators, mostly gasoline powered washing machines and pedal sewing machines, almost all with a "general farm" categorization, outdoor privies, and kerosene lighting (some gas). Based on these criteria, I have counted 105 households as Old Order Amish for this study.

The notations themselves are fascinating and, in a few cases, especially insightful. Some marginal notes demonstrate the extent to which definitive lines between women's and men's work, household and farm labor, and house and farm equipment are difficult to draw on any family farm. The situation on Old Order Amish farms was no different in the 1930s. For example, S.C.P. Agent Rigdon recorded a typical Amish response when she reported the farm and household labor arrangements of a middle-aged couple with four teenage children: "All work done within family both in house and farm” (Figure 2).

It is clear from examining these S.C.P. manuscript farm schedules from Lancaster County that the survey workers who filled out the forms did not define "Amish" by the presence or absence of technology, including automobiles, nor did the Amish family members who agreed to these lengthy interviews identify themselves by their ownership of a buggy. It is revealing to observe where survey takers tagged their surveys. In 67 of 74 cases, the telltale word "Amish" appears on the schedules identifiable as Old Order Amish most often by the recreation section. Personal care, usually notes about hair cutting, shows up 23 times, and clothing notes appear on 19 forms. Annotations about automobile expenses occur only three times, as infrequently as notes about insurance. Explaining missing recreation expenses is by far the most common notation written on these forms. 
Figure 2: Record 1017, Salisbury Township, Page 4

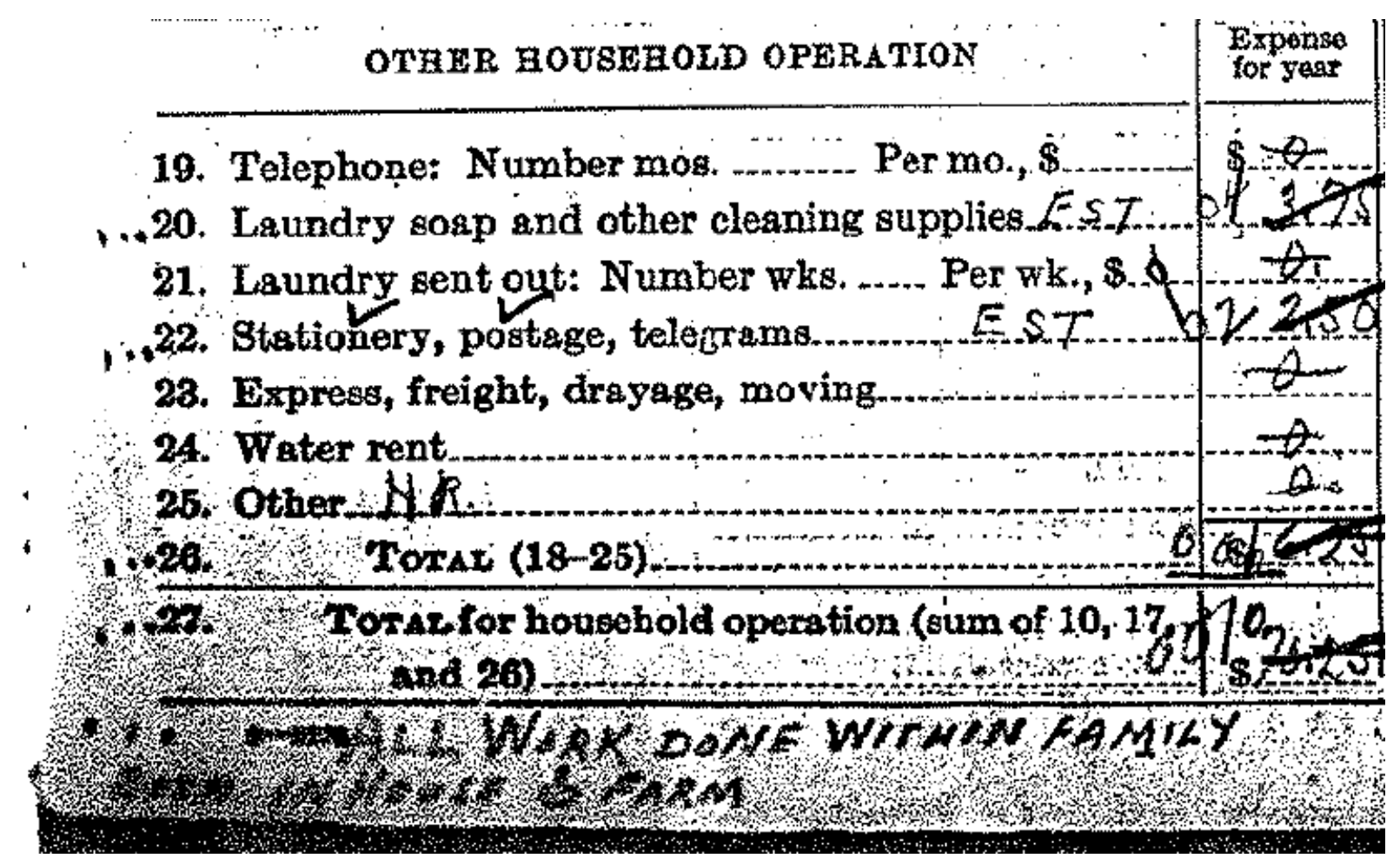

\section{Results}

The Old Order Amish in Lancaster County were not so obviously different from their farm and small town neighbors in 1935 and 1936 as they appear to be in the early twenty-first century, as shown by the I.C.P.S.R. random sample dataset. Only $34.5 \%$ of all surveyed rural households owned a phone, while $32 \%$ of these households owned no car for the entire survey year. Remarkably more rural households, 64\%, owned a radio, a new invention that could run on batteries rather than high-line electricity, and provided far flung farm families with important weather and market information as well as entertainment programming (Jellison 1993). An Amish family that rejected rural transformative technologies in the mid-1930s — no phone, no car, and no radio_ - did not stand out from its non-Amish neighbors as much as it did after the Second World War.

The 1930s was a decade of transitional differentiation between the Old Order Amish and their rural neighbors. On the one hand, farm income and expenditures were more similar than different. On the other hand, distinctions were more visible in household expenditures and production: recreation, personal care, food production and preservation, and clothing. Above all else, to the agents and their subjects, what stood out most clearly was recreation. Who would not escape the doldrums of the Great Depression at the movies, or by attending a fair or a ball game, or listening to the Yankees or farm reports on the radio, or some other activity? What man did not go to a barber for a haircut; what woman would avoid a beauty salon? Differences in the 
presence or absence of small household appliances, telephones, grid electricity, mass media, automobiles, and tractors were beginning to appear, but were not yet defining markers of distinction.

Record 1016, for example, taken in Salisbury Township, includes “Amish” in the recreation and personal care sections, and on every clothing schedule (in this case, a husband, a wife, and their five children). On page four of the second schedule, page six overall, Agent Rigdon wrote in all capital letters, "THIS IS AN AMISH FAMILY WHO DO NOT BELIEVE IN PAID-FOR RECREATION. HAIR IS ALL CUT WITHIN FAMILY” (figure 3). All three sections in the recreation category ("Paid Admission To," "Games and Sports," and "Other Recreation"), along with the personal care section, have lines drawn through them with totals of zero expenses. In addition, all seven of the clothing schedules have variations of "AMISH FAMILY WHO DO ALL THEIR OWN CLOTHING MAKING POSSIBLE.” Line 98 of the clothing schedule for the 45-year-old wife lists an expense of \$5.60 for "SPECIAL AMISH DRESS MAT[erial]” (Figure 4).

Other survey agents used different words and locations on the forms to explain the lack of any expenses in certain categories. In Record 1723, from Ephrata Township, Agent Johnson wrote "Amish Family" in script by the recreation section, although there were small expenses for children's toys and pet licenses (Figure 5). On Record 1014, from Salisbury Township, Agent Groome wrote under the personal care section, "This is an Amish family, they cut their own hair" (Figure 6). On Record 1399, from Earl Township, Agent Yecker clarified the missing personal care expenses with the notation at the bottom of the page, "This is an Amish family where the men do not shave and have large beards" (Figure 7).

Some of the clothing schedules for women and teenage girls exhibit expenses for "Bonnet” in addition to the frequent “Amish” annotation. In Record 1014, from Salisbury Township, Agent Groome wrote "Amish" in the margin next to information about the 27-yearold wife and noted that she had spent \$2.98 for a "bonnet” in autumn 1935 (Figure 8). In Record 1488, from Upper Leacock Township, “bonnet” appears on the 15-year-old daughter's clothing schedule, showing the purchase of two bonnets, one in spring 1935 and one in the fall, for a total of \$5.00 (Figure 9). Record 1488 notes “Amish” by both the recreation and personal care sections. Record 1582 has “Amish” inscribed five times over crossed-out sections, presenting a picturesque image of a frustrated Agent Veit, who may have been growing tired of writing lengthy explanations for all the zero expense categories (Figure 10).

The SCP schedules reveal other themes in addition to Old Order Amish recreational, personal care, and clothing practices. Record 1017, from Salisbury Township, clarified the lack of automobile expenses with the marginal note, “Amish do not believe in automobiles” (Figure 11). On Record 1514, Agent Rigdon explained the zero on the "Hired labor for farm" line with the note, "Have own help in sons" (Figure 12). Rigdon wrote "Amish" in this record by the recreation and personal care sections, and on all three clothing schedules. On Record 1566, 
Agent Fraser explained the \$45.00 expense on Line 9, “Taxes and insurance on farm property," by checking "Taxes" and writing at the top of the page, "Amish don't believe in ins[urance]" (Figure 13). Record 1694, from Paradise Township, includes a unique note from Agent Getz: “AMISH DO NOT SELL SUNDAY'S MILK USE IT FOR BUTTER” (Figure 14). On the same record, Agent Getz wrote more complex notations about expenses on an Amish farm. On page one of the first short form, as an elaboration on the $\$ 360.00$ figure on Line 11, "Rent for land and buildings,” Getz wrote in the right margin, “AMISH. 'NOTE' MEANS LIFE-RIGHT. AMISH CUSTOM. HE MUST PAY THIS TO PARENTS FOR USE OF FARM THOUGH IT IS HIS.” On page five of the second form, Getz wrote in Section 14, "Gifts, Community Welfare, Taxes," as an explanation for the $\$ 360$ expense on line two, "Contributions to support of relatives not members of the economic family." She also wrote "LIFE-RIGHT” just above the line.

Additionally, at the top of the section, Getz wrote, "WHEN A YOUNG AMISHMAN MARRIES THEY GIVE HIM MONEY. THIS IS CALLED AUS-STEUER (HOUSE DOWER).” The agent probably confused “Aus” with "Haus,” but Aussteuer does mean “dowry” or "endowment.” On the back of the last page, to explain the $\$ 700.00$ expense on Line 24, "Notes owed to individuals," Getz wrote, "Farmer said he paid off about $\$ 700.00$ to father. No interest” (Figure 15). Amish inheritance practices are not very visible in these expenditure surveys, since each survey covered only one year of expenses. This form does indicate the tradition of parents helping children to buy land and set up a farming operation, which is key to treating farming as a way of life rather than a business enterprise.

Figure 3: Record 1016, Salisbury Township, Page Six

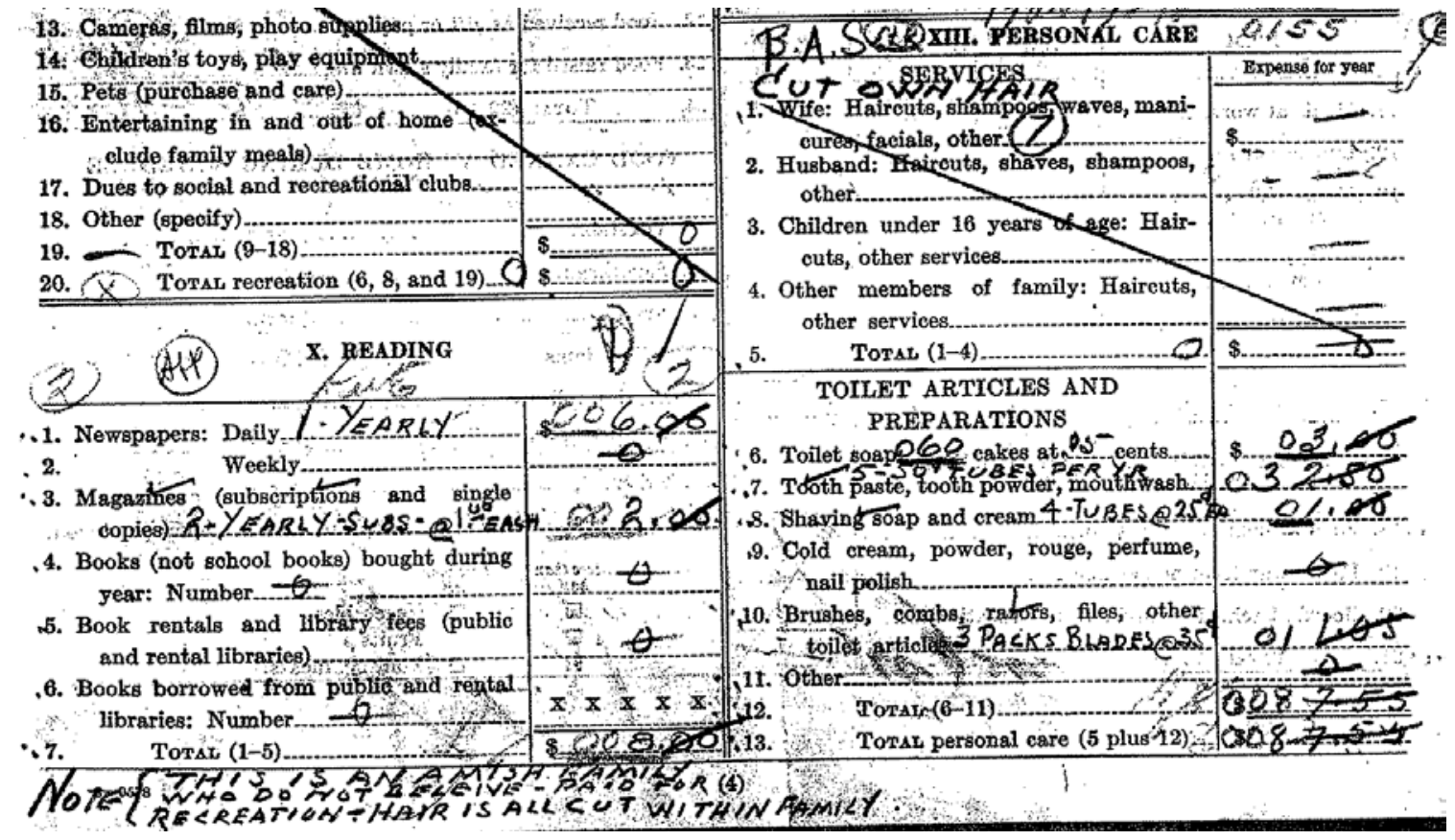




\section{Figure 4: Record 1016, Salisbury Township, Clothing Schedule}

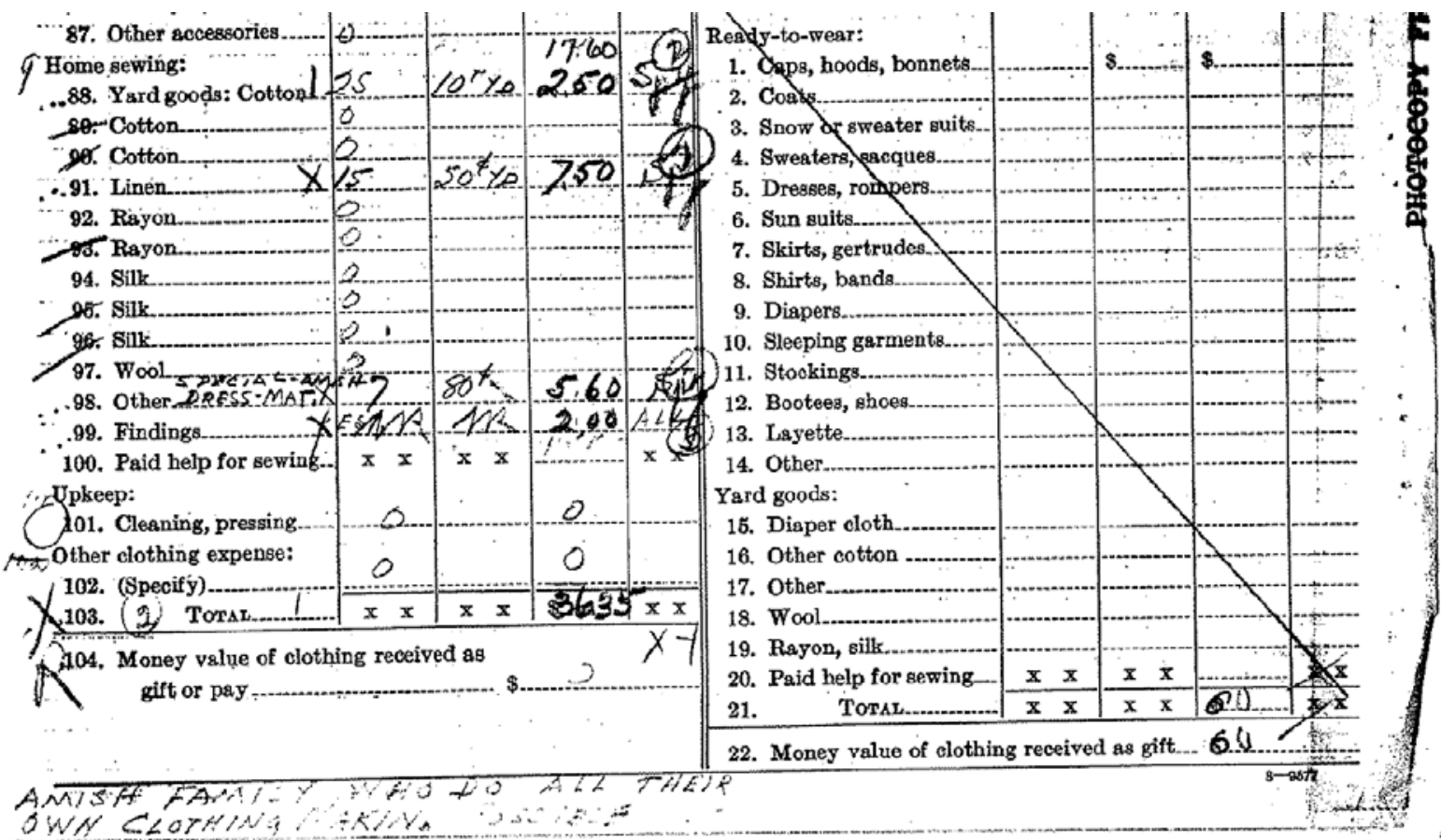

Figure 5: Record 1723, Ephrata Township

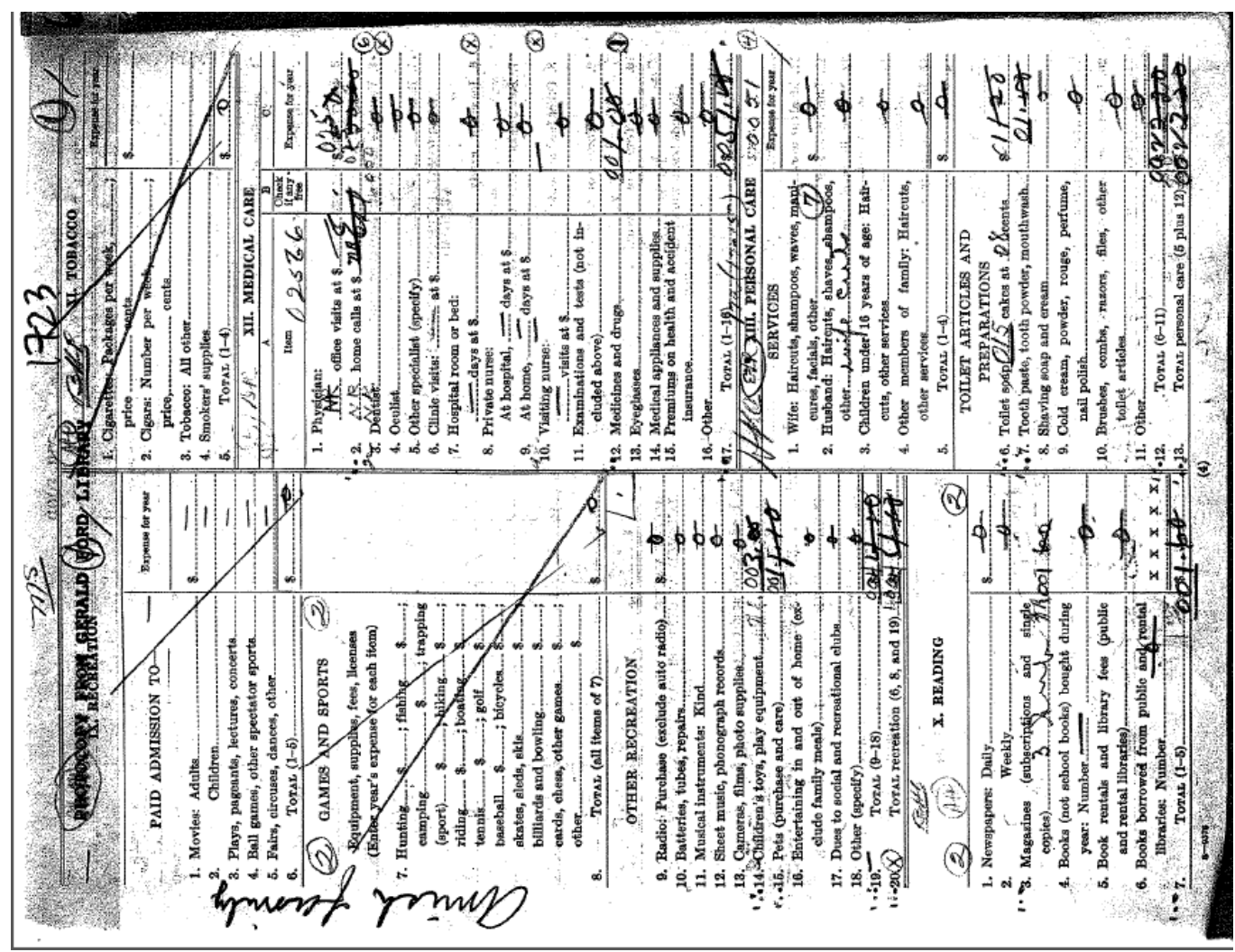




\section{Figure 6: Record 1014, Salisbury Township}

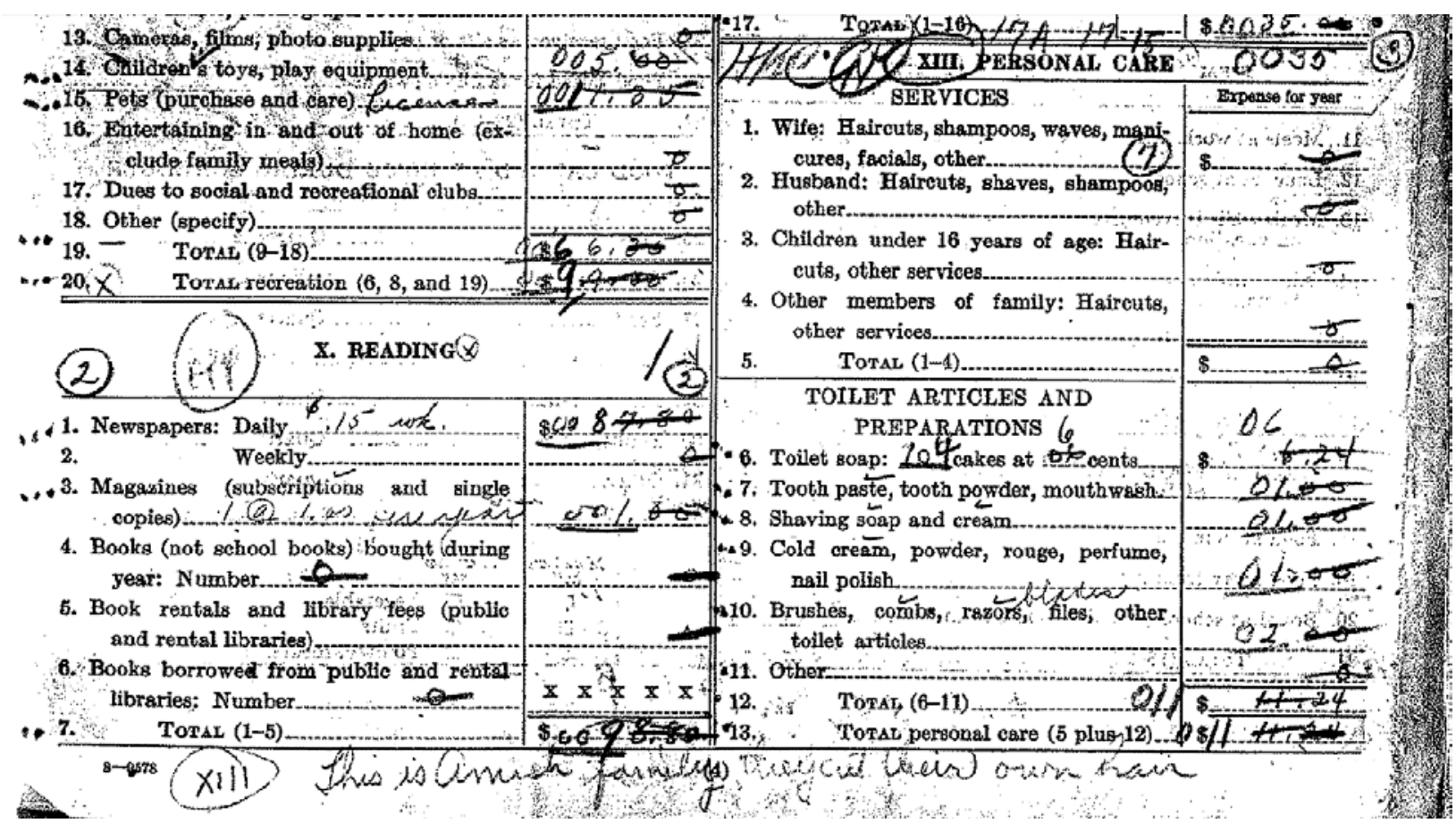

Figure 7: Record 1399, Earl Township

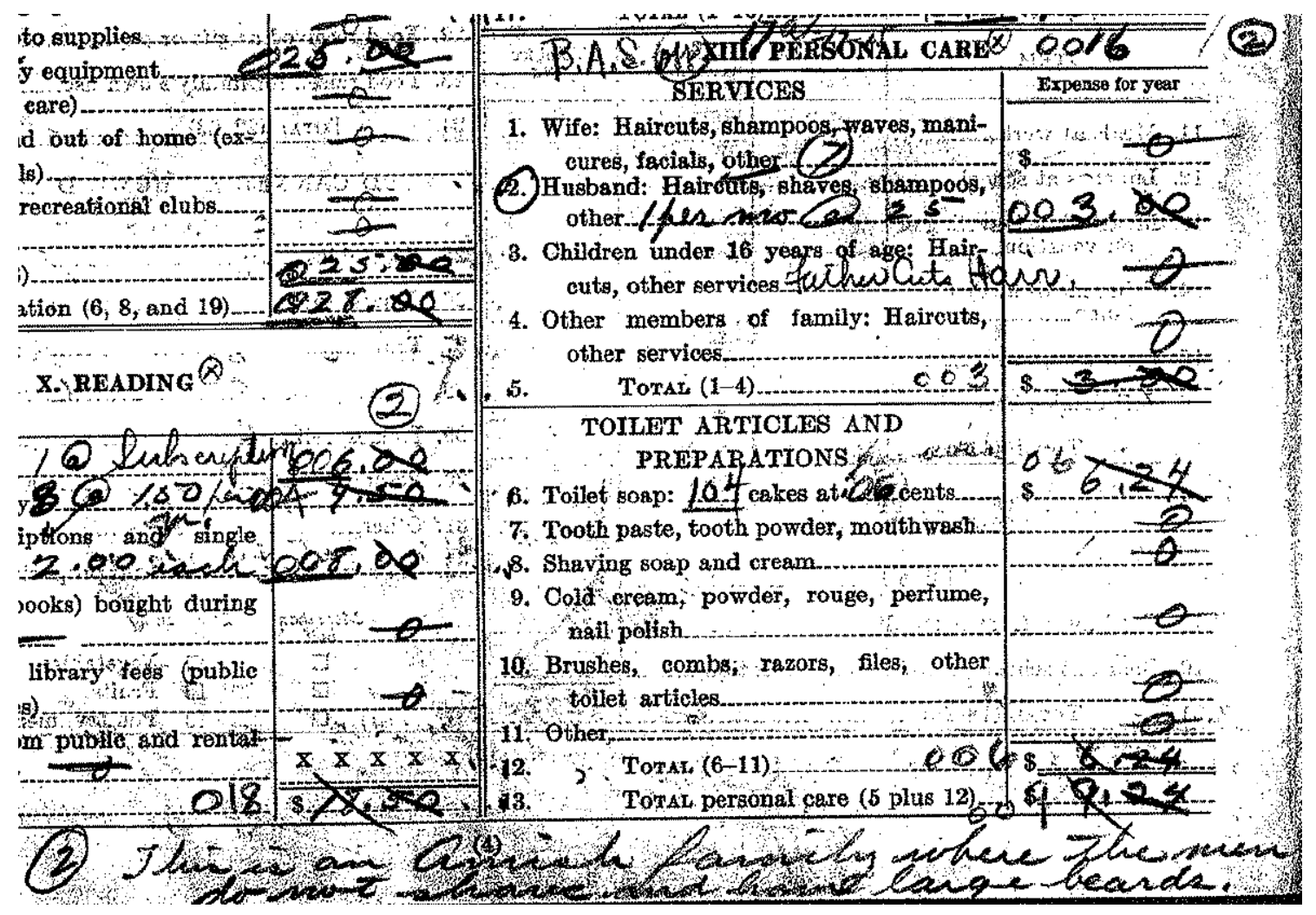




\section{Figure 8: Record 1014, Salisbury Township}

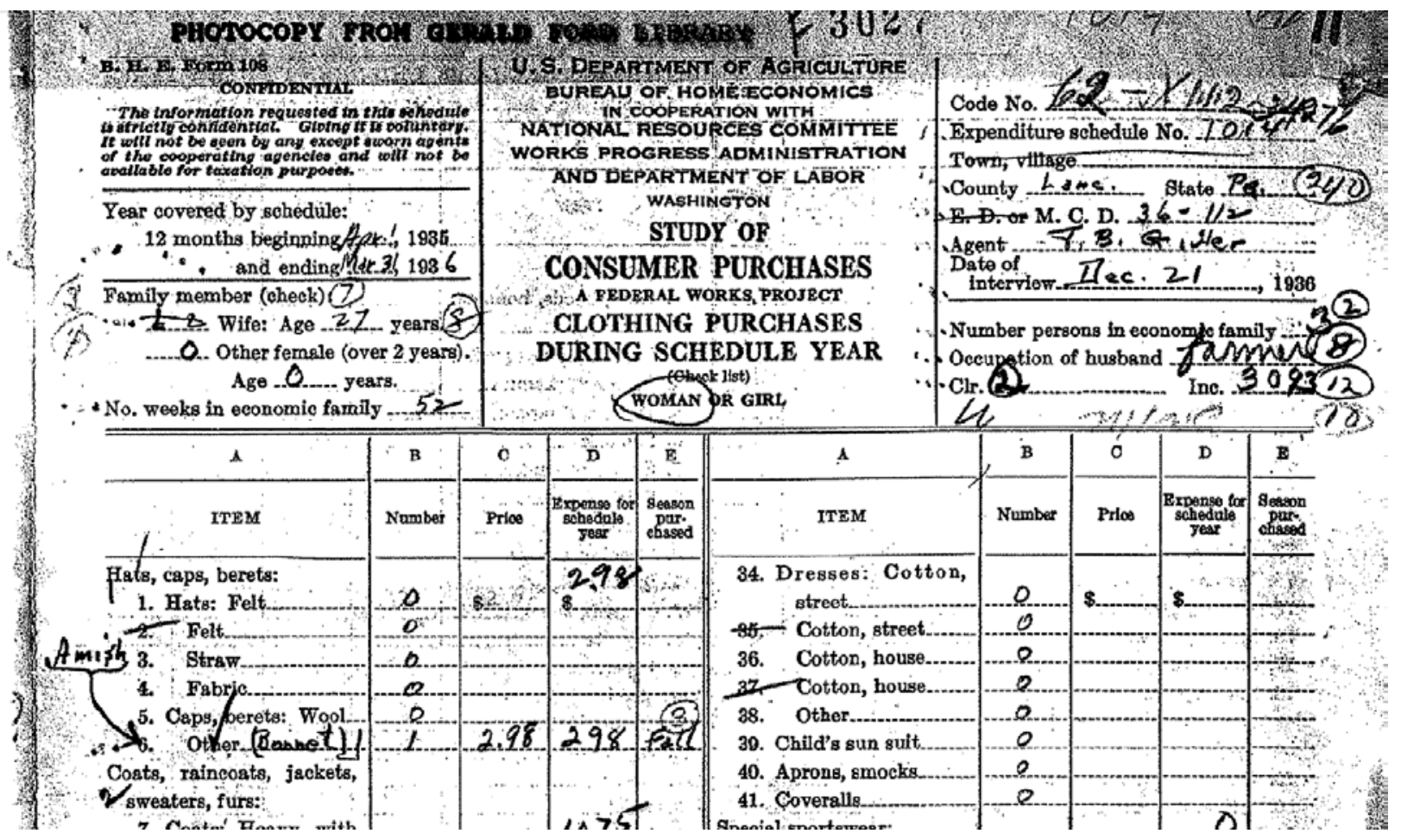

Figure 9: Record 1488, Upper Leacock Township

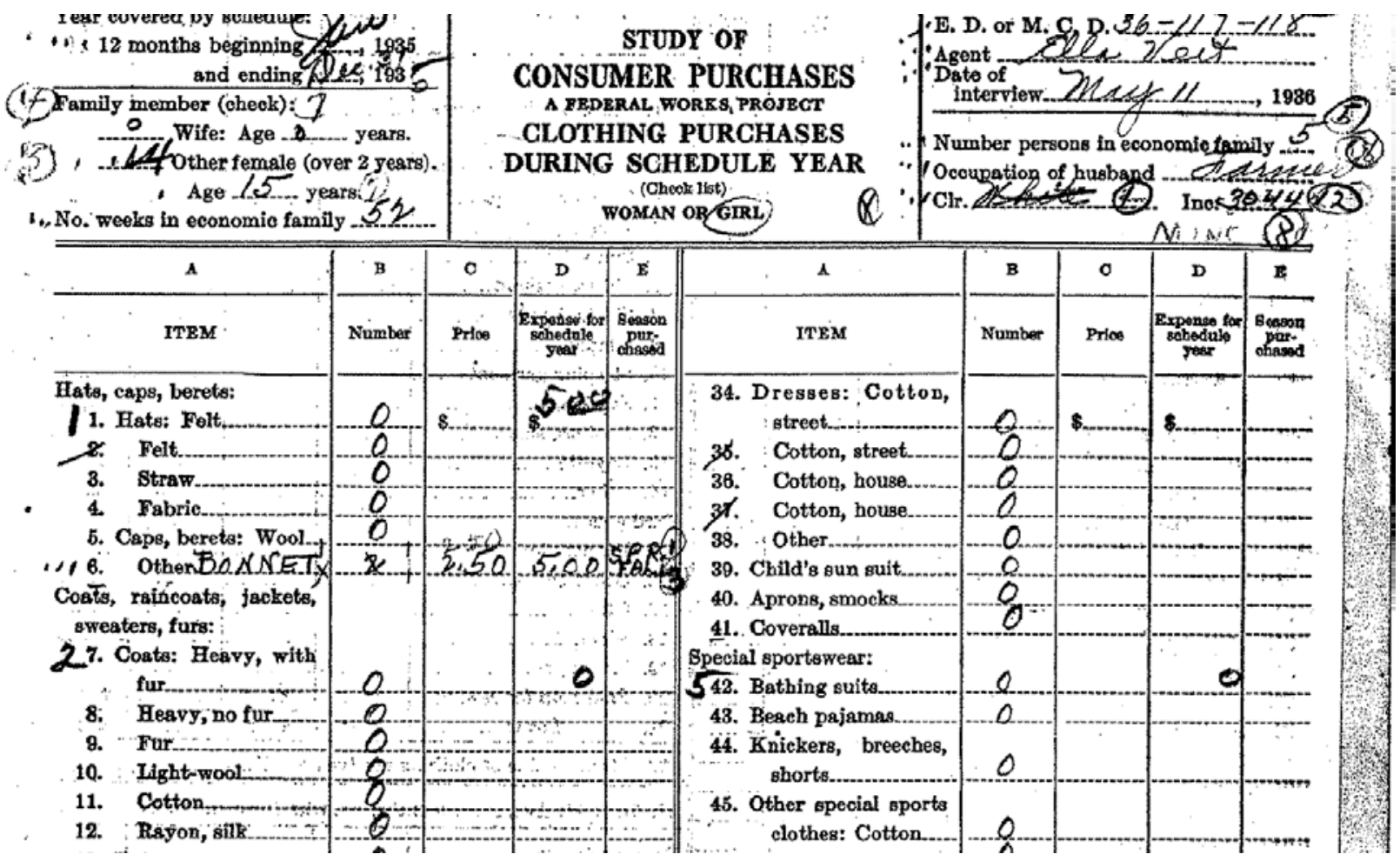




\section{Figure 10: Record 1582, Leacock Township}

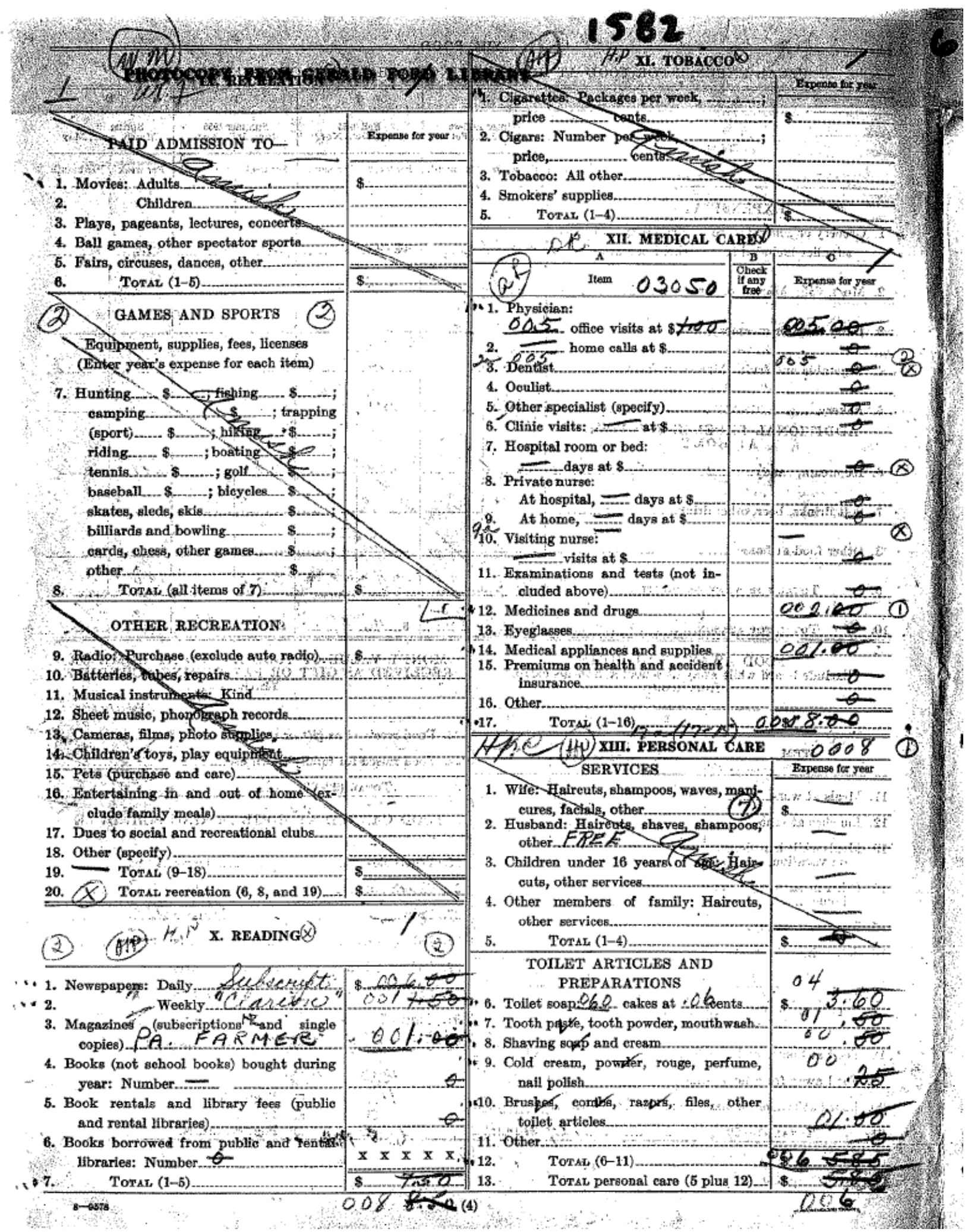




\section{Figure 11: Record 1017, Salisbury Township}

\begin{tabular}{|c|c|c|c|c|c|}
\hline HOLD BELP & $\begin{array}{l}\text { omplojed } \\
\text { (number) }\end{array}$ & 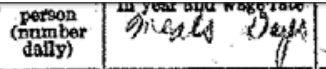 & & 19. Repairs, replaeements; service-... & \\
\hline 18 & & -hrs. & 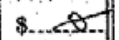 & 21. Licenses, including registration fees & \\
\hline 13. & & _-days@\$_- & & 22. Fines, damages paid others & \\
\hline 14. By week & & -wks. @\$- & 2. & 23. Automobile insurance (all types). & \\
\hline & & $=\operatorname{mos}$ & .......... & 24. Tolls (bridge, ferry, tuinel) & \\
\hline 18: Aprons fori & & Sifts to & & 25. Accessorles (include automobile radi & \\
\hline 17. Tox & $(12-16)$ & -1 & 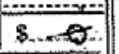 & 26. Other (include sssociation dues) & \\
\hline 18. Living qua & ers furnis & ied to: & & 28.-Proportion of sutomobile & \\
\hline a. Hel & & & & AM butiness & \\
\hline c. Help & id by we & k............... & & VII. OTHER TRAVES AND TRANSPORT & 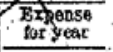 \\
\hline d. Help & aid by mo & ath.......... व & & Local-to work, schoor, stores: & \\
\hline orr & R BOUSEE & OLD OPERATION & $\begin{array}{l}\text { Exponso } \\
\text { for yoart }\end{array}$ & $\begin{array}{l}\text { 1. Bus, frolley, taxi, train, ferry, boat, rent of auto. } \\
\text { other travel (exclude business travel): }\end{array}$ & \\
\hline $\begin{array}{l}\text { 19. Telephone: } \\
\text { 20. Laundry } 8 \mathrm{c}\end{array}$ & Fumber n & er cleaning supplies_ESI & & $\begin{array}{l}\text { 2. Railroad (include Pullman) } \\
\text { 3. Interurban bus and trolley... }\end{array}$ & $-\frac{\theta}{\theta}$ \\
\hline 21. Laundry & 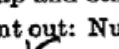 & oer wks. ...... Pe & & 4. Other (specify vehicle) & $\therefore$ \\
\hline $\begin{array}{l}\text { 22. Stationery } \\
\text { 23. Express, if }\end{array}$ & 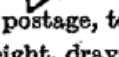 & 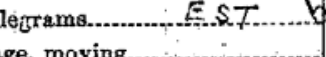 & $\theta$ & $\begin{array}{l}\text { Purchase and upkeep during year: tfa } \\
\text { 5. Of motorcycle. }\end{array}$ & -0 \\
\hline 24. Ẃate & & & & ०.6. Of horse and carriage for fam & 0502 \\
\hline 25. Other 4 & & & D. & 7 . Of boat & 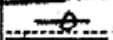 \\
\hline 1.26. $\quad \mathrm{T}_{0}$ & 18-25 & (n) & 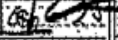 & H.8. & 020,0 \\
\hline 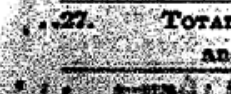 & 6 house & doperation (sum of $10,17 \mathrm{gl}$ & 100 & $\begin{array}{l}\text { 9. Proportion of motorcycle, horse and carriage, or } \\
\text { other vehicle expense chargeable to buisiness }\end{array}$ & \\
\hline
\end{tabular}

Figure 12: Record 1514, Leacock Township

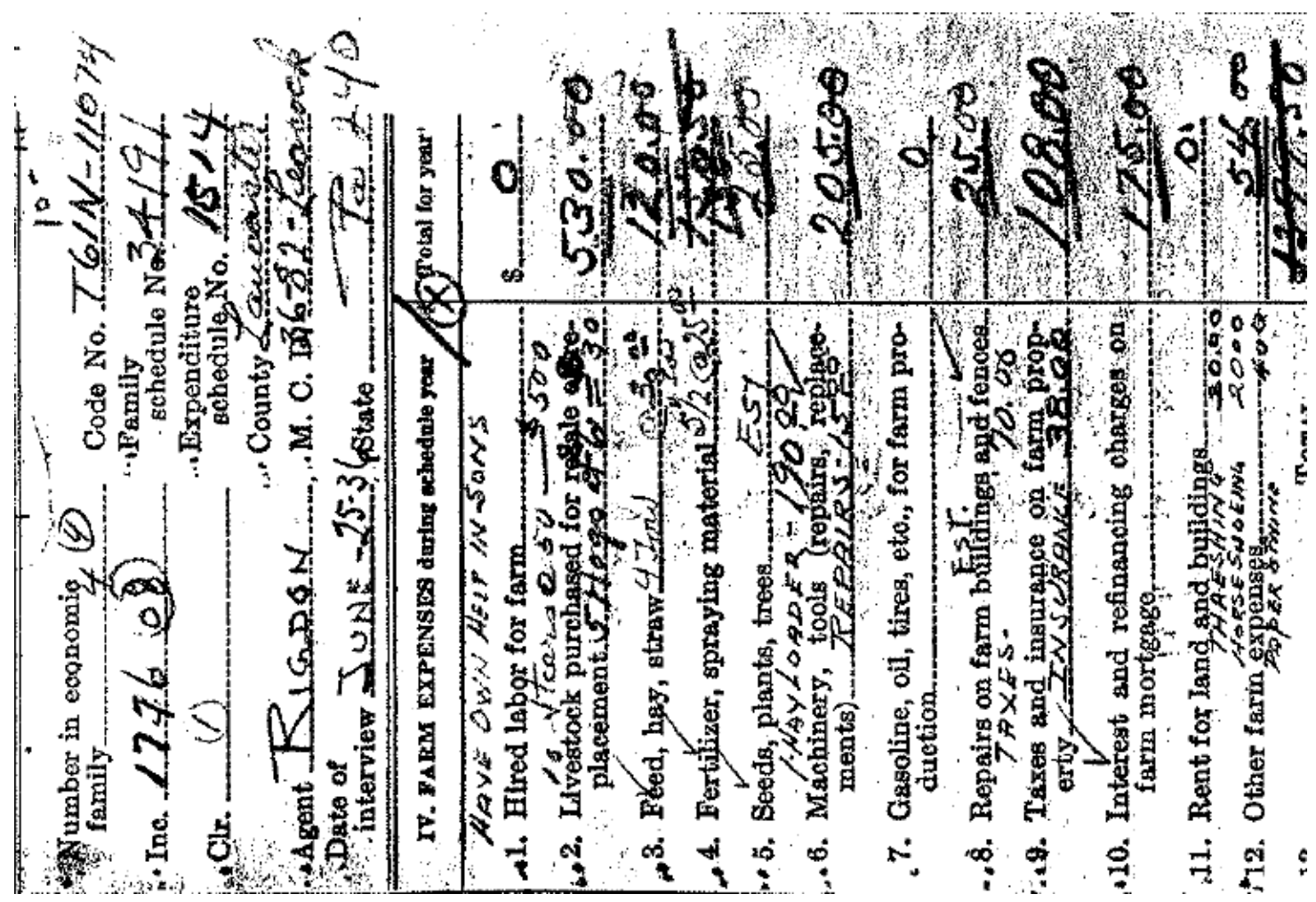


Figure 13: Record 1566, West Earl Township

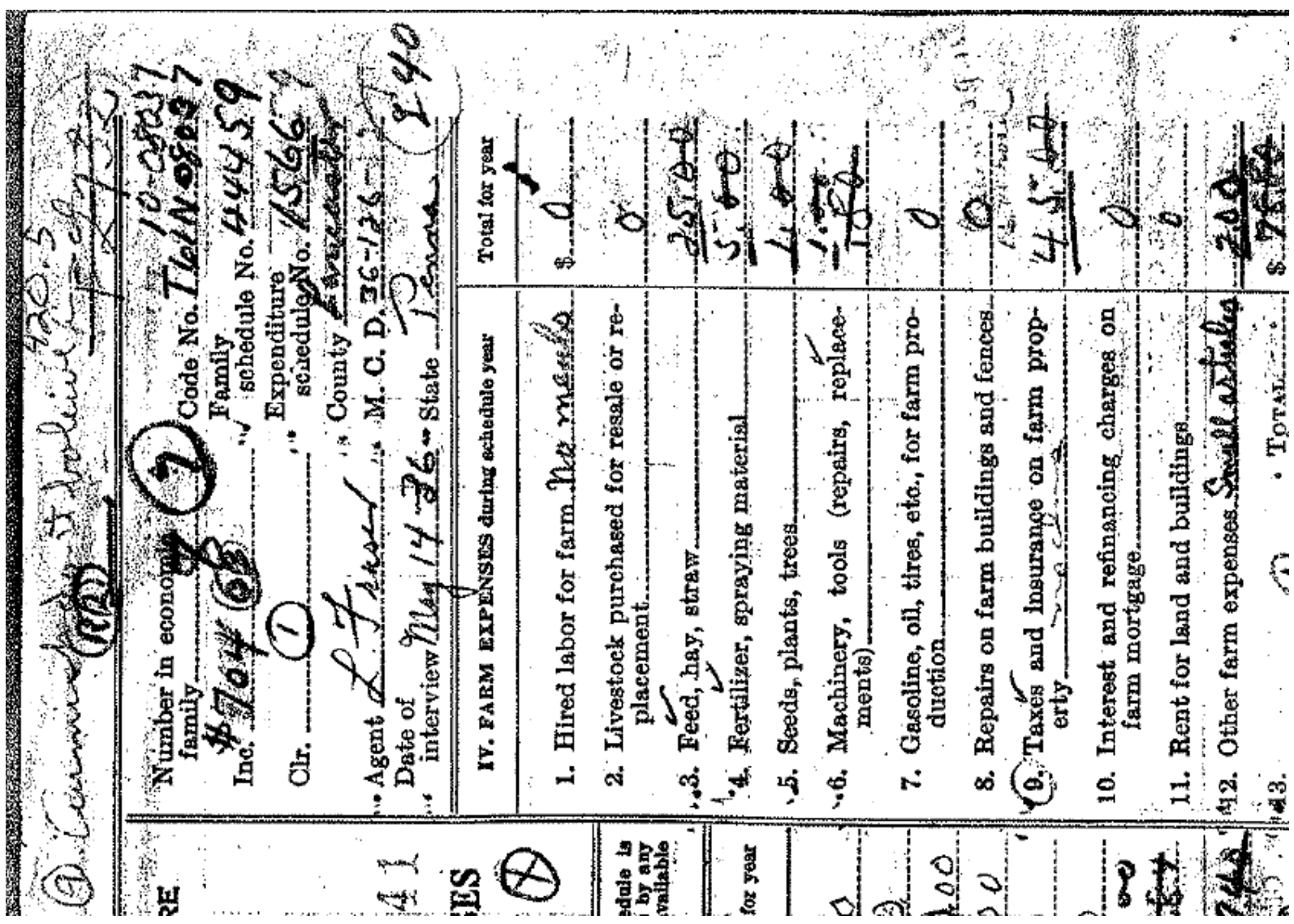

Figure 14: Record 1694, Paradise Township

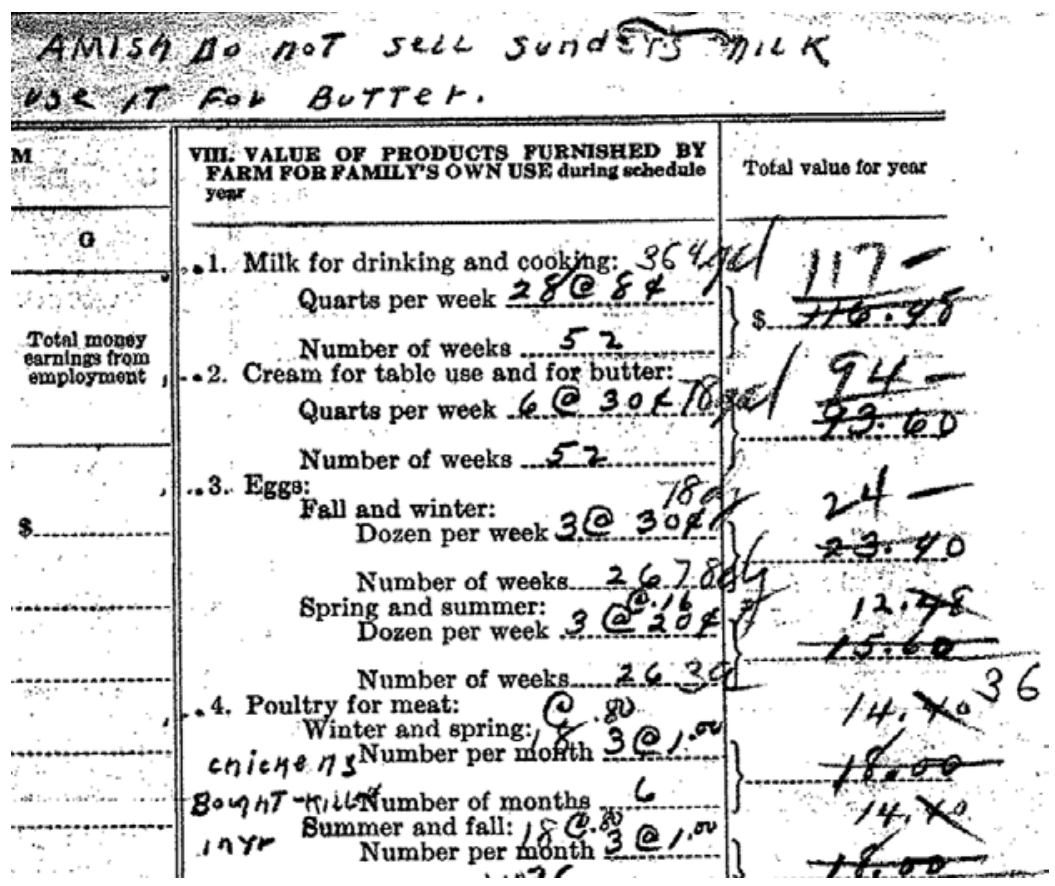


Figure 15: Record 1694, Paradise Township
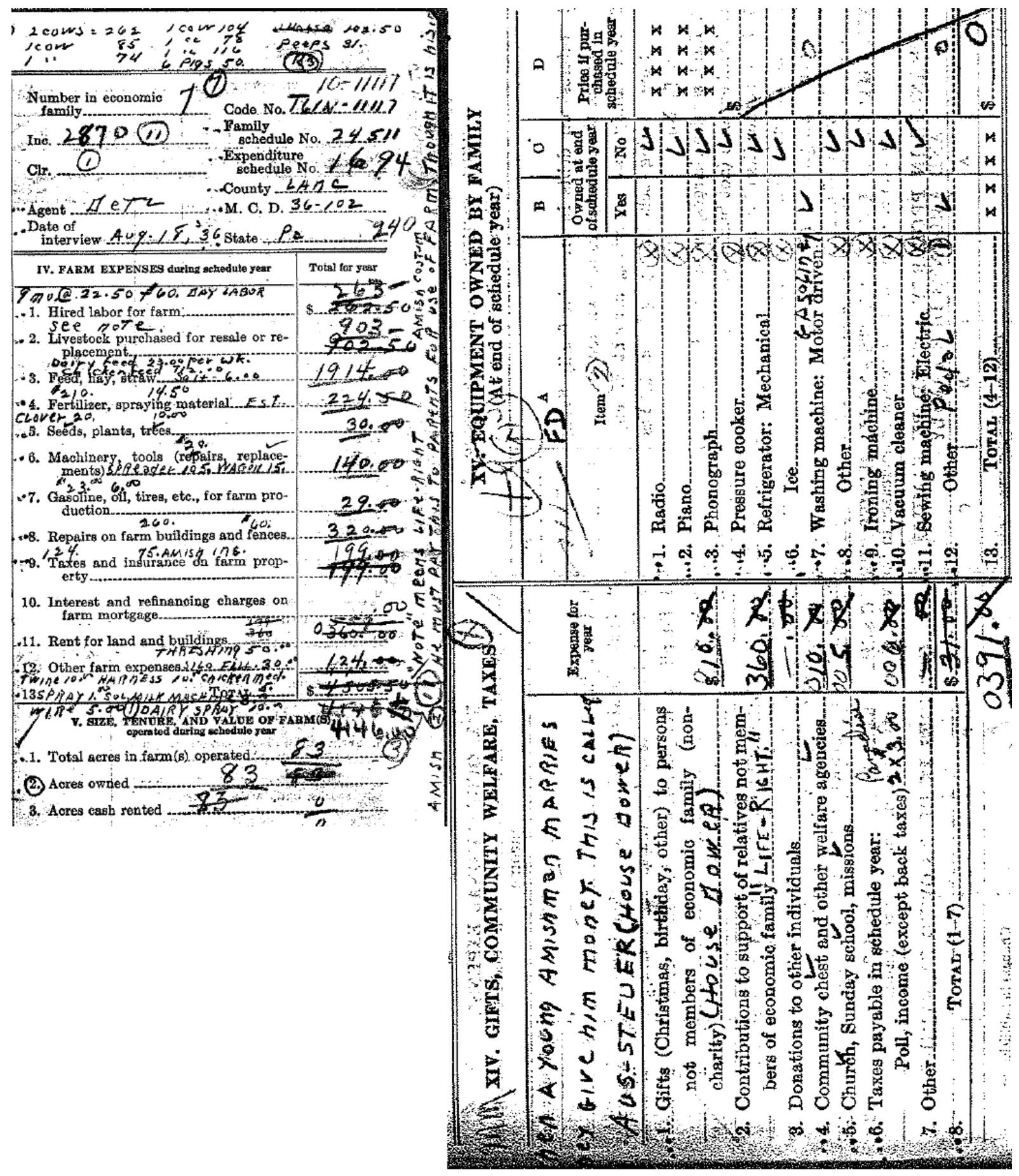

127 armen said he paid of abourt $7.0 y$ oot fother. 
In order to study the conditions promoting rural social, economic, and cultural stability, the Department of Agriculture sponsored six rural community studies in the early 1940s, with the Amish anchoring the stability end of a theoretical stability-instability continuum. Their attraction to the government as a rural model was not based on rejection of technology, but rather on general farming, low overhead costs of farming, and especially the work of women and children in the house, garden, barn, and land. They refused to adopt emerging communication, transportation, housekeeping, and contraceptive technologies, the specific examples of which include telephones, radios, automobiles, electrical appliances, and birth control devices. At a time when a high school education was becoming a universal experience throughout the rest of the northern United States, the Old Order Amish, in keeping with their tradition, refused to send their children to school beyond the eighth grade (Meyers 2003). Most significantly, as America became increasingly urbanized and industrialized, the Old Order Amish remained committed to an agrarian way of life. They farmed in Lancaster County and other areas of Amish settlement without the benefit of tractors - relying instead on the power of horses and mules - and at a time when other farmers were becoming able to specialize in production of a few major cash crops, the Old Order Amish continued their tradition of general, diversified farming to provide for the agricultural market and at the same time feed their own families. Old Order Amish men and women believed that the Bible sanctioned their devotion to an agrarian way of life, just as it did their other distinctive practices. As a Lancaster County Amish man told cultural geographer Walter M. Kollmorgen in 1940, "[T]he Lord told Adam to replenish the earth and to rule over the animals and the land-you can’t do that in cities” (Getz 1946; Kollmorgen 1942).

Given the modernization efforts of many New Deal programs that focused on rural America, such as the Rural Electrification Administration, government researchers like Kollmorgen, who conducted his research as an employee of the federal Bureau of Agricultural Economics (B.A.E.), might have been expected by the business-oriented factions in the Department of Agriculture to portray Amish women and men as quaint, outmoded-even ignorantly stubborn - hangers-on to the obsolete traditions of another era. However, it was their very uniqueness that rendered the Old Order Amish a desirable population of study to the small family farm faction in the Department. The Amish community's successful reliance on an older way of agrarian life, at a time when many "modern” farms were failing, intrigued these investigators. They suspected that perhaps traditional Amish family farming, in which both male and female members continued to play an active role in farm production, represented a viable alternative to mechanized, business-oriented agriculture (Jellison 2001; Jellison 2002; Kirkendall 1966; Gilbert 2001; Salamon 1992).

\section{Conclusion}

The relative insignificance of technology in identifying Amish households as Amish in the 1935 and 1936 Study of Consumer Purchases serves to clarify how and why some officials of the federal government were so interested in the Amish of Lancaster County during the Great 
Depression. Rejecting the trend toward capital-intensive mechanized farming and convenienceoriented housekeeping in favor of cultural and religious traditions, the Lancaster County Amish successfully maintained their small-scale, labor-intensive, general farms beyond the economic crisis of the 1930s. The Amish continued to filter and selectively adapt new technologies in ways that preserved their small-scale values as the larger society around them accelerated its pace of technological and cultural change, resulting in increasingly visible and striking differences in relation to their host societies. By the early twenty-first century, the Amish were so starkly different from mainstream culture that they have become the titillating subject of many reality television programs, romance novels, provocative documentaries, and many other appearances in American popular culture. (Zimmerman-Umble and Weaver-Zercher 2008; Trollinger 2012; Weaver-Zercher 2013)

\section{Endnotes}

${ }^{1}$ Steven D. Reschly is professor of history at Truman State University.

2“Study of Consumer Purchases in the United States, 1935-1936,” organized and conducted by the United States Department of Labor, Bureau of Labor Statistics, Cost of Living Division; United States Department of Agriculture, Bureau of Home Economics, Economics Division; United States National Resources Committee, Consumption Research Staff, Industrial Section; United States Central Statistical Board; and United States Works Progress Administration. Study of Consumer Purchases records are held in National Archives Record Group 176. The planning map in Figure 1 is located in Box 6, Folder 1. The Consumer Purchase Study Records will hereafter be cited as C.P.S.R. The farm family survey folders will be cited by record number, taken from the "Expenditure schedule number" on each form, one of several code numbers used to identify and organize the surveys. Organizers went to great lengths to protect the anonymity of the respondents, and I have made no attempt to identify individual families or farm properties.

3“Instructions for Collection of Schedules: Farm” (31 March 1936), Box 2, Folder 2, C.P.S.R. For more on interest within the U.S.D.A. in the Amish of Lancaster County, Pennsylvania, see Jellison (2001) and Jellison (2002).

${ }^{4}$ Random Sample ICPSR08908-v3 (Ann Arbor, MI: Inter-university Consortium for Political and Social Research [distributor], 2009-06-29), doi:10.3886/ICPSR08908.v3. Persistent URL: http://dx.doi.org/10.3886/ICPSR08908.v3

${ }^{5}$ The instructions to field agents to fill in every line on every form are very specific and compelling. Day Monroe, “Farm Family Schedules,” 20 June 1936; “Completing Family Schedules from Farm Families,” 16 July 1936; “Standards for Schedule Rejection,” 18 July 1936, C.P.S.R., Box 4 Folder 4. 


\section{References}

Anderson, J. L. 2009. Industrializing the Cornbelt: Agriculture, Technology, and the Environment. DeKalb, IL: Northern Illinois University Press.

Barron, Hal S. 1997. Mixed Harvest: The Second Great Transformation in the Rural North. Chapel Hill, NC: University of North Carolina Press.

Beachy, LeRoy. 2011. Unser Leit: The Story of the Amish. Millersburg, OH: Goodly Heritage Books.

Danbom, David. 2006. Born in the Country: A History of Rural America. Baltimore, MD: Johns Hopkins University Press.

Getz, Jane C. 1946. "The Economic Organization and Practices of the Old Order Amish of Lancaster County, Pennsylvania.” Mennonite Quarterly Review 20(1):53-80 and 20(2):98-127.

Gilbert, Jess. 2001. “Agrarian Intellectuals in a Democratizing State: A Collective Biography of USDA Leaders in the Intended New Deal.” Pp. 213-239 in The Countryside in the Age of the Modern State: Political Histories of Rural America, edited by Catherine McNicol Stock and Robert D. Johnston. Ithaca, NY: Cornell University Press.

Gingerich, Melvin. 1939. The Mennonites in Iowa; Marking the One Hundredth Anniversary of the Coming of the Mennonites to Iowa. Iowa City, IA: The State Historical Society of Iowa.

Inter-university Consortium for Political and Social Research (I.C.P.S.R.). Random Sample ICPSR08908-v3. Ann Arbor, MI: Inter-university Consortium for Political and Social Research [distributor], 2009-06-29, doi:10.3886/ICPSR08908.v3. Persistent URL: (http://dx.doi.org/10.3886/ICPSR08908.v3).

Jellison, Katherine. 1993. Entitled to Power: Farm Women and Technology, 1913-1963. Chapel Hill, NC: University of North Carolina Press.

Jellison, Katherine. “An ‘Enviable Tradition’ of Patriarchy: New Deal Investigations of Women's Work in the Amish Farm Family.” Pp. 240-257 in The Countryside in the Age of the Modern State: Political Histories of Rural America, edited by Catherine McNicol Stock and Robert D. Johnston. Ithaca, NY: Cornell University Press, 2001.

Jellison, Katherine. 2002. “Chosen Women: The Amish and the New Deal.” Pp. 102-118 in Strangers at Home: Amish and Mennonite Women in History, edited by Kimberly D. Schmidt, Diane Zimmerman Umble, and Steven D. Reschly. Baltimore, MD: Johns Hopkins University Press. 
Jellison, Katherine. 2014. "Research Note: Amish Women and the Household Economy during the Great Depression.” Mennonite Quarterly Review, 88(1):97-105. As corrected online (https://www.goshen.edu/mqr/pastissues/Jan14Jellison.pdf)

Johnson-Weiner, Karen M. 2014. “Technological Diversity and Cultural Change among Contemporary Amish Groups.” Mennonite Quarterly Review 88(1):5-23.

Kirkendall, Richard Stewart. 1966. Social Scientists and Farm Politics in the Age of Roosevelt. Columbia, MO: University of Missouri Press.

Kollmorgen, Walter M. 1942. Culture of a Contemporary Rural Community: The Old Order Amish of Lancaster County, Pennsylvania. Rural Life Studies, Vol 4. Washington, DC: Government Printing Office.

Konersmann, Frank. 2008. “Toleration, Privilege, Assimilation and Secularization: Mennonite Communities of Faith in the Palatinate, Rhine-Hesse and the Northern Upper Rhine, 1664-1802.” Mennonite Quarterly Review 82(4):533-567.

Konersman, Frank. 2012. "Middle-Class Formation in Rural Society: Mennonite Peasant Merchants in the Palatinate, Rhine Hesse, and the Northern Rhine Valley, 1740-1880.” Mennonite Quarterly Review 86 (2):229-263. Trans. John D. Roth.

Konersmann, Frank, and Klaus-Joachim Lorenzen-Schmidt (eds). 2011. Bauern als Händler: Ökonomische Diversifizierung und sociale Differenzierung bäuerlicher Agrarproduzenten (15.-19. Jahrhundert). Stuttgart, Germany: Lucius \& Lucius.

Kraybill, Donald B. (ed). 2003 The Amish and the State. Baltimore, MD: Johns Hopkins University Press.

Kraybill, Donald B., and Marc A. Olshan (eds). 1994. The Amish Struggle with Modernity. Hanover, NH: University Press of New England.

Kraybill, Donald B., Karen M. Johnson-Weiner, and Steven M. Nolt. 2013. The Amish. Baltimore, MD: The Johns Hopkins University Press.

Loewen, Royden. 2006. Diaspora in the Countryside: Two Mennonite Communities and MidTwentieth-Century Rural Disjuncture. Urbana, IL: University of Illinois Press.

Meyers, Thomas J. 1993. "Education and Schooling.” Pp. 87-106 in The Amish and the State edited by Donald B. Kraybill. Baltimore, MD: Johns Hopkins University Press.

Monroe, Day. “Farm Family Schedules,” 20 June 1936; “Completing Family Schedules from Farm Families,” 16 July 1936; “Standards for Schedule Rejection,” 18 July 1936. Consumer Purchase Study Records, Box 4 Folder 4. 
Nolt, Steven M. 2003. A History of the Amish. Intercourse, PA: Good Books.

Petrovich, Christopher G. 2014. "Technology in the Service of Community: Identity and Change among the Andy Weaver Amish.” Mennonite Quarterly Review 88(1):23-64.

Reschly, Steven D. 2000. The Amish on the Iowa Prairie, 1840-1910. Baltimore, MD: Johns Hopkins University Press.

Reschly, Steven D., and Katherine Jellison. 199. "Production Patterns, Consumption Strategies, and Gender Relations in Amish and Non-Amish Farm Households in Lancaster County, Pennsylvania, 1935-1936.” Agricultural History 67(2):134-162.

Salamon, Sonya. 1992. Prairie Patrimony: Family, Farming, and Community in the Midwest. Chapel Hill. NC: University of North Carolina Press.

"Study of Consumer Purchases in the United States, 1935-1936," organized and conducted by the United States Department of Labor, Bureau of Labor Statistics, Cost of Living Division; United States Department of Agriculture, Bureau of Home Economics, Economics Division; United States National Resources Committee, Consumption Research Staff, Industrial Section; United States Central Statistical Board; and United States Works Progress Administration. Study of Consumer Purchases Records (S.C.P.R.) are held in National Archives Record Group 176.

Trollinger, Susan. 2012. Selling the Amish: The Tourism of Nostalgia. Baltimore: John Hopkins University Press.

Weaver-Zercher, David. 2001. The Amish in the American Imagination. Baltimore, MD: John Hopkins University Press.

Weaver-Zercher, Valerie. 2013. Thrill of the Chaste: The Allure of Amish Romance Novels. Baltimore, MD: Johns Hopkins University Press.

Yoder, Paton, and Steven R. Estes. 1999. Proceedings of the Amish Ministers' Meetings, 18621878. Goshen, IN: Mennonite Historical Society.

Yoder, Paton. 1991. Tradition and Transition: Amish Mennonites and Old Order Amish, 18001900. Scottdale, PA: Herald Press.

Zimmerman Umble, Diane. 1996. Holding the Line: The Telephone in Old Order Mennonite and Amish Life. Baltimore, MD: Johns Hopkins University Press.

Zimmerman Umble, Diane and David L. Weaver-Zercher (eds). 2008. The Amish and the Media. Baltimore, MD: Johns Hopkins University Press. 


\section{Appendix A}

Table 2: “Amish” on Schedules

\begin{tabular}{|l|l|}
\hline Recreation & 67 (of 74 cases) \\
Hair/personal care & 23 \\
Clothing & 19 \\
Automobile & 3 \\
Insurance & 3 \\
Tobacco & 2 \\
Inheritance/land & 1 \\
Sunday’s milk (products for family’s use) & 1 \\
\hline
\end{tabular}

Table 3: Transitional Differentiation: Equipment Owned for All or Part of Year

\begin{tabular}{lll}
\hline Total Cases* & 3,034 & $100 \%$ \\
Phone & 1,048 & $34.5 \%$ \\
Piano & 973 & $32.1 \%$ \\
Phonograph & 668 & $22,0 \%$ \\
Radio & 1,943 & $64.0 \%$ \\
Refrigerator & 657 & $21.7 \%$ \\
Pressure cooker & 257 & $8.5 \%$ \\
Power washing machine & 1,301 & $42.9 \%$ \\
Ironing machine & 126 & $4.2 \%$ \\
Vacuum cleaner & 955 & $31.5 \%$ \\
Sewing machine & 328 & $10.8 \%$ \\
Pedal sewing machine & 1,791 & $59 \%$ \\
Auto & 969 & $32 \%$ \\
\hline \multicolumn{2}{c}{ * I.C.P.S.R. Sample, Farm / Town }
\end{tabular}

